\title{
Population Spatial Dynamics of Larix potaninii in Alpine Treeline Ecotone in the Eastern Margin of the Tibetan Plateau, China
}

\author{
Jia'nan Cui ${ }^{1,2}$ iD, Jihong Qin ${ }^{3}$ and Hui Sun ${ }^{1, *}$ \\ 1 Department of Environmental Science and Engineering, College of Architecture and Environment, \\ Sichuan University, Chengdu 610065, China; jncui1015@pku.edu.cn \\ 2 State Key Joint Laboratory of Environmental Simulation and Pollution Control, College of Environmental \\ Sciences and Engineering, Peking University, Beijing 100871, China \\ 3 School of Architecture and Civil Engineering, Chengdu University, Chengdu 610106, China; \\ floodqjh@gmail.com \\ * Correspondence: sunhuifiles@gmail.com; Tel.: +86-139-8181-5710
}

Received: 20 July 2017; Accepted: 18 September 2017; Published: 22 September 2017

\begin{abstract}
The high-altitude treeline is known to be sensitive to climate variability, and is thus considered as a bio-monitoring indicator of climate change. However, our understanding of the population dynamics and the cumulative climate-change effects on the alpine treeline ecotone in recent decades is limited. Here, we investigated the population dynamics of Larix potainii on the southand north-facing slopes in the alpine treeline ecotone in the eastern margin of the Tibetan Plateau, China, including treeline position, population density, and tree recruitment. Results showed that on both south- and north-facing slopes, the treeline did not show a significant advancement in the past four decades. The population was dominated by young individuals, which tend to be established in the lower areas. Larix, here, tends to be clustered, especially in the upper areas. However, population density increased dramatically only on north-facing slopes. Larix here suffer from the stressful environment, but the warmer winter due to climate warming could facilitate the vertical growth of seedlings and saplings. Aggregated spatial patterns also provide a positive feedback in ameliorating the harsh environment. The slope-climate-moisture interactions have a pronounced impact on tree recruitment, including snow-limited tree establishment on the north-facing slopes and moisture-limited tree establishment on the south-facing slopes.
\end{abstract}

Keywords: alpine treeline ecotone; climate change; population dynamics; Tibetan Plateau; treeline advance

\section{Introduction}

Global warming is considered to be one of the most significant factors that has caused the greatest changes of ecosystems in high altitudes and latitudes during the last century [1]. The alpine treeline ecotone is the transitional zone from the timberline to the tree species limit, where the timberline is the upper delimitation of the closed forest and the tree species line is the uppermost location of seedlings or saplings [2,3]. As the natural boundary of high-altitude ecosystems, the alpine treeline ecotone is widely assumed as the early-warning monitor of climate change for its sensitivity to climate change [4]. The treeline is the upper altitudinal limit at which upright trees reach two meters in height [5-7]. Given the importance of environmental factors in controlling the position of the treeline and affecting tree recruitment, the alpine treeline ecotone is thought to be vulnerable to climate change, showing changes in density dynamics, recruitment patterns, and treeline positions [5,8-11].

Treeline studies have used three general approaches to assess treeline position: long-term monitoring of the permanent plots, remote sensing, and mainly aerial photographs and stand 
structure/treeline reconstruction by using tree-rings [12-14]. One of the main factors that controls treeline ecotones is the climate, and in particular, the sustained increasing temperature [10]. The prevailing perspective is that the changes of summer temperatures strongly affect the treeline position during the vegetation period [15], although several studies also indicated the importance of winter temperatures [16]. However, the expansion of trees to higher elevations is not universal. In an extensive assessment of 166 treeline studies globally, treelines were found to be advancing at $52 \%$ of these sites since 1900s, stable at $46 \%$, and retreating at $2 \%$ [13]. While treelines in the Scandes and Central Himalayas have risen $200 \mathrm{~m}$ and $300 \mathrm{~m}$ in recent decades, respectively, there has not been significant treeline advance in the Barun Valley, the Alps, or Alaska [2,16-18]. The variability of treeline response to temperature indicates that temperature may not be the dominant factor controlling the treeline position in some regions. Temperature can interact with other factors such as precipitation, plant-plant interactions, wind exposure, topography, snow cover, and land-use changes [9,18-21].

In fact, treeline advance is proven to be the result of the establishment of young individuals in treeless areas or even beyond the present treeline rather than the growth of mature trees [22,23]. Spatial and temporal patterns of tree populations may play a significant role in treeline dynamics [24,25]. In several study regions, the amount of recent young trees has increased or is increasing in the lower and middle areas of the ecotone, revealing a rising population density rather than treeline advance [7,26]. Contrarily, in other areas, new establishment has led to the infilling of existing trees and possible treeline upslope movement, apparently reflecting an amelioration of the environment in the treeless areas with wind exposure, ice particle abrasion, and thin snow cover [13,20]. Trees, once established in the treeless areas within the treeline ecotone or beyond the present treeline, may serve as seed sources and change the microclimate $[27,28]$. However, this is not necessarily related to the advance of the treeline position, which is probably a much more complex process and would take several decades or even centuries [22].

The alpine treeline at the Tibetan Plateau (TP) in China is the highest treeline in the world and is considered to be especially sensitive to global climate change [14]. The treeline here is frequently situated above $4000 \mathrm{~m}$ above sea level (a.s.1.) [29]. Changing treeline ecotones, with both population dynamics and treeline location, have been reported mainly for the central, northern, and southern TP during recent decades $[2,14,18,30]$. However, the TP climate is under the combined and competitive influence of South Asian and East Asian Monsoons as well as the mid-latitude westerlies. The observed climate data in the eastern margin and other region of the TP exhibited different characteristics and trends [31]. Therefore, there is a need for more field-based data to understand the treeline ecotone dynamics in the eastern margin of the TP, where the related study is lacking. Moreover, the treeline dynamics vary with the area-specific climate and slope exposure [18,32-34]. A study focusing on multiple aspects will be able to interpret the slope exposure effects on the alpine treeline ecotone.

To understand the population dynamics and the cumulative climate-change effects on the alpine treeline ecotone in the eastern margin of the TP, we selected various sites on the north-facing and south-facing slopes. The density, recruitment pattern, and treeline dynamics of the treeline forming species Larix potaninii var. macrocarpa [35] were analyzed to address the following research questions: (i) What are the treeline ecotone dynamics in the eastern margin of the TP, including density, recruitment, and treeline position? Are there any differences between the two different slopes? (ii) What are the roles of two primary drivers, temperature and precipitation, in treeline ecotone dynamics? Are there any other factors, such as slope exposure and snowpack, limiting the tree regeneration and treeline movements?

\section{Materials and Methods}

\subsection{Study Area and Site Selection}

The study was carried out in the alpine natural forest in Sichuan Province, China, which is on the eastern margin of the Tibetan Plateau $\left(101^{\circ} 40^{\prime}-102^{\circ} 50^{\prime} \mathrm{E}, 29^{\circ} 50^{\prime}-30^{\circ} 50^{\prime} \mathrm{N}\right)$ (Figure 1$)$. At the treeline 
ecotone, the soil is brown coniferous forest soil with an average $\mathrm{pH}$ value of 4.9. Along the altitudinal gradient, the floristic composition of the treeline ecotone here is co-dominated by Larix potaninii var. macrocarpa, Abies forrestii, and A. squamata, whereas, from 3800 to $4000 \mathrm{~m}$ a.s.1., pure forest of Larix is prevalent. Larix belongs to the genus Larix within family Pinaceae, and is a prominent component of subalpine forests [35]. In addition, the forest understory is dominated by shrubs like Sorbus rehderiana, Ribes tenue, Lonicera szechuanica, and Acanthopanax giraldii. No grasses for yak grazing exist. Thus, the Larix treeline in Western Sichuan Province is highly representative of natural treelines on the eastern margin of the TP.

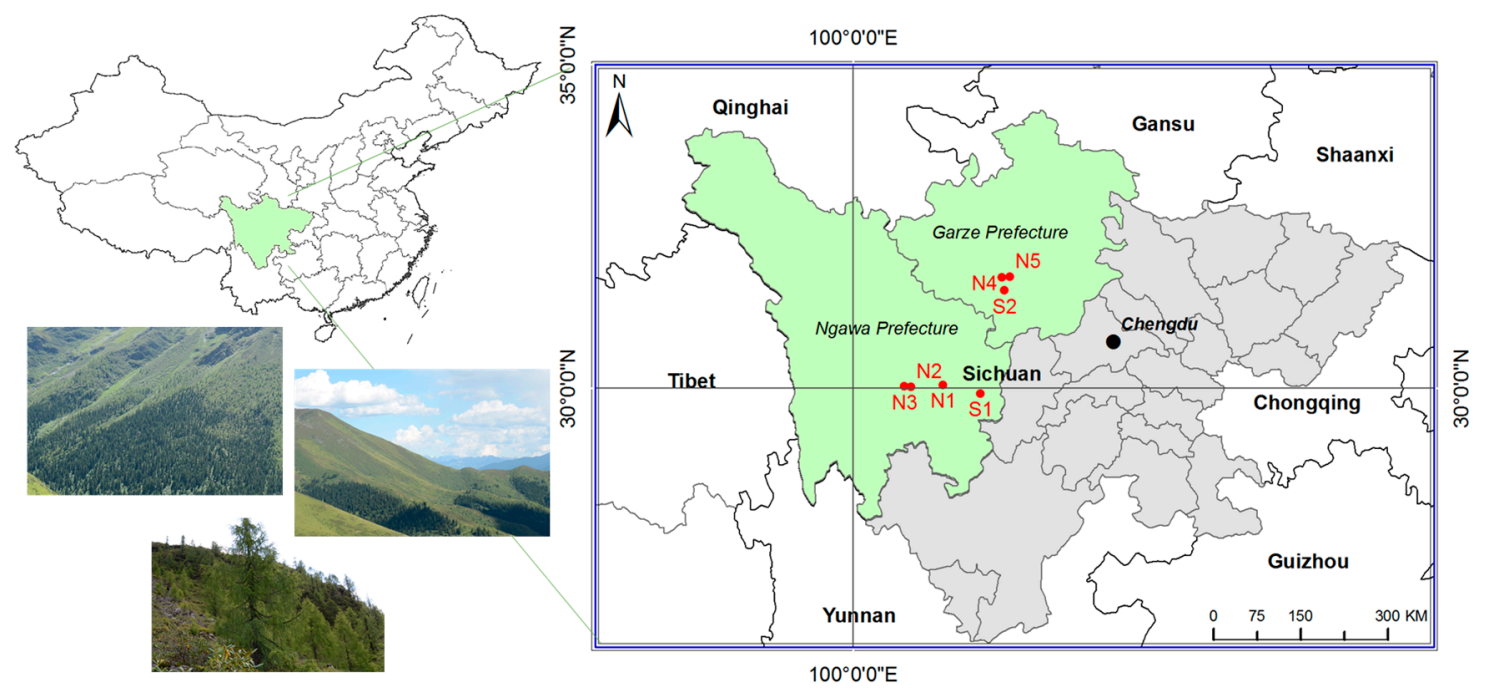

Figure 1. Map showing the location of the study region and seven sampling sites in the alpine treeline ecotone in Western Sichuan, China. Sites N1, N2, N3, N4, N5 are on the north-facing slopes, and sites S1, S2 are on the south-facing slopes. Photographs show the forests in our sampling sites. Left top: N2, right top: N5, and bottom: S1.

Field investigation was conducted in from August to November 2015. Altogether, seven sites were selected in the alpine treeline ecotone in the Ngawa Tibetan and Qiang Autonomous Prefecture and the Garzê Tibetan Autonomous Prefecture, respectively (Figure 1, Table 1): five sites on north-facing slopes ( sites N1, N2, N3, N4, N5) and two on south-facing slopes (sites S1, S2). All of the sites had continuous forest distribution and had not been disturbed by humans or animals. At each site, rectangular plots with three or four replicates were established on a topographically uniform area. For each site, the point $(x, y)=(0,0)$ was located at the bottom left corner. The width of the horizontal side (x-axis) ranged from 15 to $40 \mathrm{~m}$ and the vertical side (y-axis) of each site was from the forestline to the tree species limit to cover the entire treeline ecotone.

\subsection{Climate Data}

The eastern margin of the TP is characterized by a semi-humid climate with wet summers and dry winters, with most precipitation falling between June and September [14,31]. Five nearby meteorological stations from samplings sites are mainly located in the regional county (Table A1), and Kangding station stopped recording the data in 1982. Thus, the data from these meteorological station are not precise enough for our high-elevation mountain studies [2,18]. To give an overview of the recent climate trend in the seven sampling sites, we presented gridded monthly temperature and precipitation data (Climate Research Unit (CRU) 3.23 at $0.5^{\circ}$ spatial resolutions, http:/ / www. cru.uea.ac.uk/data/) [2,36]. As the sampling sites N2 and N3, N4 and N5 were quite near to each other (the distance between N2 and N3, N4 and N5 was $1.7 \mathrm{~km}$ and $3.3 \mathrm{~km}$, respectively), we used the same climate data for each of them. In total, five series of climate data were collected. The correlation 
between climate data from the CRU and regional meteorological station during the period of 1971-2014 were statistically significant in our research as well as in other studies (Table A2) [37].

Table 1. Characteristics of seven sampling sites in the eastern Tibetan Plateau (TP) and the numbers of sampled individuals.

\begin{tabular}{ccccccc}
\hline Site Code & $\begin{array}{c}\text { Elevation } \\
\text { (m a.s.l.) }\end{array}$ & $\begin{array}{c}\text { Slope } \\
\text { Inclination }\end{array}$ & $\begin{array}{c}\text { Slope } \\
\text { Aspect }\end{array}$ & $\begin{array}{c}\text { Horizontal } \\
\text { Length }(\mathbf{m})\end{array}$ & $\begin{array}{c}\text { Vertical } \\
\text { Length }(\mathbf{m})\end{array}$ & $\begin{array}{c}\text { Numbers. of } \\
\text { Larix Individuals }\end{array}$ \\
\hline N1 & 4015 & $30^{\circ}$ & NW $30^{\circ}$ & 20 & 15 & 14 \\
N2 & 4274 & $20^{\circ}$ & NE $50^{\circ}$ & 40 & 25 & 27 \\
N3 & 4293 & $25^{\circ}$ & NW $50^{\circ}$ & 25 & 20 & 31 \\
N4 & 4076 & $30^{\circ}$ & NW 53 & 30 & 40 & 24 \\
N5 & 4076 & $35^{\circ}$ & N & 15 & 35 & 25 \\
S1 & 3698 & $25^{\circ}$ & SW 75 & 40 & 30 & 35 \\
S2 & 4214 & $25^{\circ}$ & S & 30 & 100 & 39 \\
\hline
\end{tabular}

Notes: In the column of slope aspect, NW means north-west, NE means north-east, N means north, and SW means south-west aspect.

According to the CRU climate data during the period of 1971-2014 [36], the mean annual temperature of this study area was about $6.2^{\circ} \mathrm{C}$, with a seven-month cold season (from the previous October to the present April, in which the monthly average temperature is below $10^{\circ} \mathrm{C}$ ). January (mean temperature of $\left.-2.7^{\circ} \mathrm{C}\right)$ and July $\left(13.5^{\circ} \mathrm{C}\right)$ were the coldest and warmest months, respectively. The annual total precipitation was $731 \mathrm{~mm}$; January $(1.3 \mathrm{~mm})$ and August $(226.5 \mathrm{~mm})$ were the two months with the least and most monthly average precipitation, respectively.

Sites $\mathrm{N} 4$ and $\mathrm{N} 5$ receive the highest annual average temperature $\left(7.2^{\circ} \mathrm{C}\right)$ with the lowest annual rainfall $(666 \mathrm{~mm})$ (Figure 2). Site S1 receives the highest annual rainfall $(807 \mathrm{~mm})$ with an annual average temperature of $6.8{ }^{\circ} \mathrm{C}$. As shown in Figure 3, in each site the gridded average annual temperature shows a significant increasing trend since 1990, a trend that is mainly driven by increases in winter temperature (November-March). Average temperature at each site also shows weak increasing trends in spring (April-May), summer (June-August), and autumn (September-October). Total annual precipitation at sites N1, N2, and N3 shows significant increasing trends over time, but showing a slight decreasing trend at sites N4, N5, S1, and S2. Precipitation in summer shows a significant increasing trend in each site.

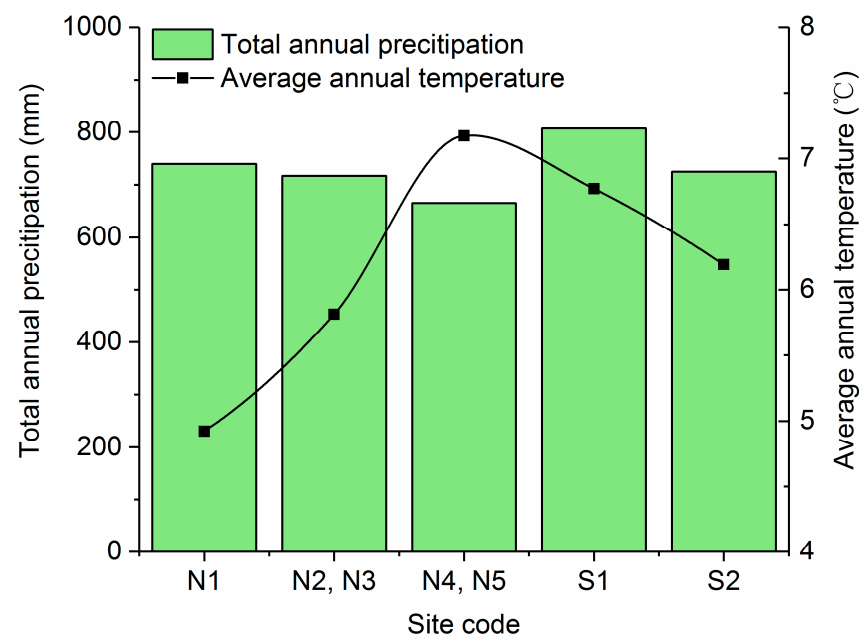

Figure 2. Total annual precipitation and average annual temperature in seven sampling sites in the alpine treeline ecotone in the eastern Tibetan Plateau during the period of 1971-2014. The meteorological data were acquired from a gridded CRU dataset (Climate Research Unit, 3.23 at $0.5^{\circ}$ spatial resolutions, http:/ / www.cru.uea.ac.uk/data/). Note the left y-axis is for precipitation and the right $\mathrm{y}$-axis is for temperature. 
Average temperature
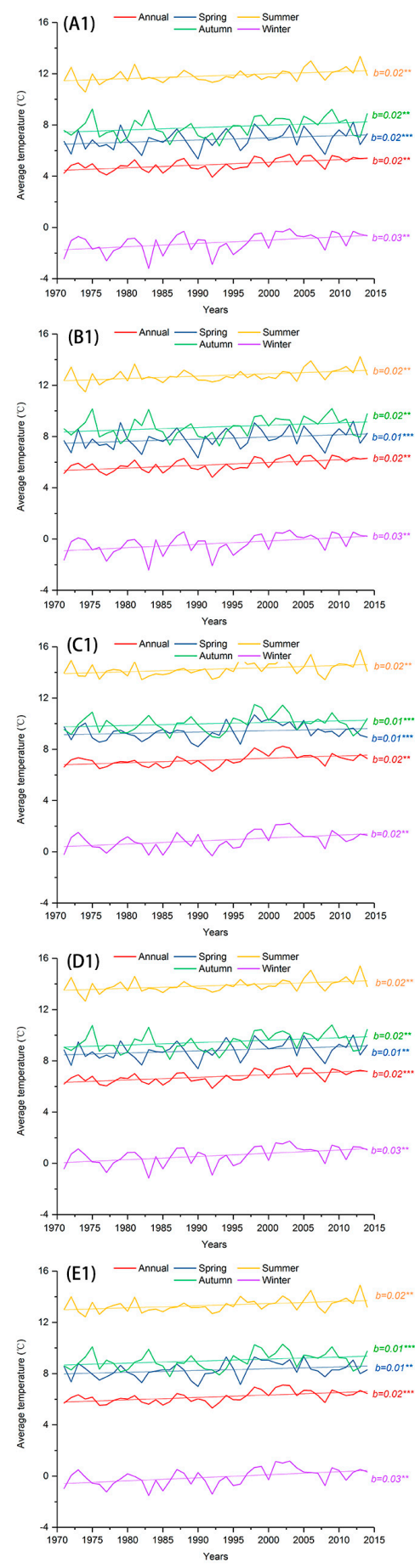

Total precipitation
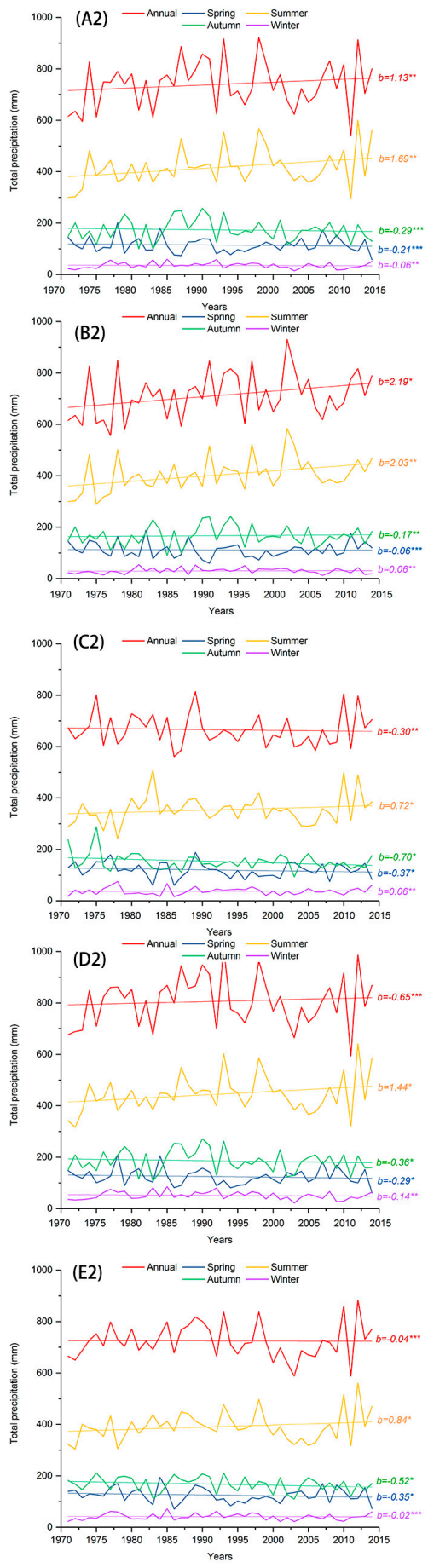

Figure 3. Temperature and precipitation trends in seven sampling site in the alpine treeline ecotone in the eastern Tibetan Plateau during the period of 1971-2014 ((A1): temperature of site N1; (A2): precipitation of site N1; (B1): temperature of sites N2 and N3; (B2): precipitation of sites N2 and N3; (C1): temperature of sites N4 and N5; (C2): precipitation of site N4 and N5; (D1): temperature of site S1; (D2): precipitation of site S1; (E1): temperature of site S2; and (E2): precipitation of site S2). Data were acquired from a gridded CRU dataset (Climate Research Unit, 3.23 at $0.5^{\circ}$ spatial resolutions, http:/ / www.cru.uea.ac.uk/data/). Trends of annual and seasonal (spring, summer, autumn, winter) total precipitation, as well as average annual and seasonal temperature are shown here. $\beta$ is the slope of the trends. ${ }^{*} p<0.05 ;{ }^{* *} p<0.01 ;{ }^{* *} p<0.001$. 


\subsection{Field Investigation and Tree-Age Estimation}

In each site, the point $(x, y)=(0,0)$ in each plot was located with GPS (Trimble Juno 3, Trimble Inc., Westminster, CO, USA) and all Larix individuals were located by recording the relative coordination to the $(0,0)$ corner. All trees (height $\geq 2 \mathrm{~m}$ ), saplings (height $0.5-2 \mathrm{~m}$ ), and seedlings (height $<0.5 \mathrm{~m}$ ) [18,38] were sampled for height and diameter at breast height (DBH, $1.3 \mathrm{~m}$ ). For those too young to measure $\mathrm{DBH}$, diameters at base (about $5 \mathrm{~cm}$ from ground) were measured instead [11]. In total, 195 Larix individuals in seven sites were measured. Other information such as the crown width of Larix individuals and the living conditions of plant communities were also recorded.

In order to construct the age structure of Larix individuals, several approaches were applied, including the dendrochronological procedure. At each site, tree-ring cores (for most trees) perpendicular to the slope line were extracted at DBH with an increment borer, ensuring that each core reached the pith of the tree $[39,40]$. Cores of poor quality or which could not be cross-dated were discarded [30]. Tree cores were prepared for further analyses by following standard dendrochronological procedures [30,40-42]. Cores were mounted, air dried, and polished with progressively finer sandpaper for visual cross-dating [41]. The age of cored samples was then determined by ring counts using a stereomicroscope [2]. For the small individuals (seedlings and saplings) from which could not be taken, the ages were determined by counting the number of branch nodes on the main stems [2,7]. This method, however, could underestimate the true age [38], thus an age-height regression method was carried out to determine the time to reach DBH in order to remove any age error. Age-height correlation and regression analyses showed statistically significant relationships between the tree age and the height of Larix trees (north-facing slopes: $y=8.48 \exp (0.27 x)$, $R^{2}=0.72, p<0.01$; south-facing slopes: $y=12.94 \exp (0.11 x), R^{2}=0.54, p<0.01 ; x$ is for tree age and $y$ is for height). Larix takes almost 12 years to reach DBH (coring-height age). Dates of tree establishment were then calculated based on tree age at the time of sampling (August-November 2015) and by adding the appropriate age to the coring-height correction.

\subsection{Treeline Dynamics}

The elevation and establishment year of all individuals including trees, saplings, and seedlings within the sampling sites were analyzed. The position of treelines in the past and present were identified by the presence of the uppermost upright tree with a minimum height of $2 \mathrm{~m}$ [14]. Treeline dynamics were then evaluated by comparing the elevation of the past treelines with the present one [2]. In addition, mean treeline was defined as the average elevation of the treeline trees (upright height $>2 \mathrm{~m}$ ) [18]. Here, the areas below and above the mean treeline in the sampling sites were termed the 'lower areas' and 'upper areas', respectively.

\subsection{Recruitment and Density Dynamics}

Recruitment and density dynamics of Larix at different elevations (the upper areas; the lower areas) within each site were determined on the timescale from 1971 to 2014. The recruitment dynamics of Larix were reconstructed using the age structure of the community for each site, and the age structure was constructed according to the tree age using 10-year age classes. Stand density was defined as the total numbers of individuals divided by the area $\left(\mathrm{ha}^{-1}\right)$.

To detect the regeneration-climate relationship and identify the critical factor in influencing tree species' population dynamics, Pearson correlation analyses were applied on the population density dynamics and monthly meteorological data, using the bivariate correlation functions in SPSS (version 21.0; SPSS Inc., Chicago, IL, USA). These monthly meteorological data included the total monthly precipitation and monthly average temperature from the previous October to the current September during the period of 1971-2014. 


\subsection{Spatial Distribution Pattern}

The spatial distribution pattern could show the history of interactions among individuals [43]. A spatial distribution pattern is expected to have three types: random, uniform (over-dispersed), and aggregated (clustered) [44]. The individuals of a species are defined to be at random if the position of each individual plant is independent of that of all the others. Uniform populations are those in which the plants are more evenly spaced than they normally would be due to competition for soil nutrients or shading effects. Aggregated populations are those in which there is a tendency for individuals of the species to occur in clumps [43]. Each sampling was divided into small sampling plots $(1 \times 1 \mathrm{~m})$ for further spatial analysis. Spatial patterns of Larix with different age classes in each sampling site were examined over a 20-year interval on the timescale from 1971 to 2014. Additionally, indices at different elevations (the upper areas; the lower areas) within the sampling site were also compared. The detection of spatial distribution pattern was implemented by using the following quadrat-base indices [45].

Index of dispersion $(D I)$ : Index of dispersion $=$ Variance $/$ mean $\left(S^{2} / \bar{X}\right), D I<1$ for more uniform, $D I=1$ for random, $D I>1$ for more aggregated.

Lloyd's mean crowding $\left(m^{*}\right)$ : Loyd's mean crowding $=\bar{X}+(D I-1), m *<\bar{X}$ for more uniform $m *=\bar{X}$ for random, $m *>\bar{X}$ for more aggregated.

Green's index $(C x)$ : Green's index $\left.=\left(S^{2} / \bar{X}-1\right) /(n-1)\right), C x<0$ for more uniform, $C x=0$ for random, $C x>0$ for more aggregated.

Clump intensity index $(P I)$ Clump intensity index $=\bar{X}^{2} /\left(S^{2}-\bar{X}\right)$, PI $\rightarrow+\infty$ for more random, PI of a lower value for more aggregated.

\section{Results}

\subsection{Treeline Dynamics}

As shown in Figure 4, the elevation of treeline position was higher than $4000 \mathrm{~m}$ a.s.l. in all sites except for S1. The present treeline is located at $4016.6 \mathrm{~m}, 4276.5 \mathrm{~m}, 4298.2 \mathrm{~m}, 4085.7 \mathrm{~m}, 4088.6 \mathrm{~m}$, $3703.1 \mathrm{~m}$, and $4152.8 \mathrm{~m}$ in N1, N2, N3, N4, N5, S1, and S2 sites, respectively. The elevation of the oldest treeline during the sample period was $4011.1 \mathrm{~m}, 4275.6 \mathrm{~m}, 4291.6 \mathrm{~m}, 4272.2 \mathrm{~m}, 4072.1 \mathrm{~m}, 3691.7 \mathrm{~m}$, and $4145.9 \mathrm{~m}$ in N1, N2, N3, N4, N5, S1, and S2 sites, respectively. Analysis of the treeline dynamics showed that the treeline advanced by $5.5 \mathrm{~m}$ in the last 36 years in $\mathrm{N} 1$, only $0.9 \mathrm{~m}$ in the last 78 years in N2, $6.6 \mathrm{~m}$ in the last 46 years in N3, $13.5 \mathrm{~m}$ in last 47 years in N4,16.5 $\mathrm{m}$ in the last 90 years in N5, $11.4 \mathrm{~m}$ in the last 60 years in S1, and $6.9 \mathrm{~m}$ in the last 32 years in S2. The treeline in N1, N2, N3, and S2 remained stable. Treelines in sites N4, N5, and S2 displayed slight upslope movements. In general, Larix treelines did not show a significant advancement in our study region.

The mean treeline, upper areas, and lower areas within each site were identified and are shown in Figure 4. The elevation of the mean treeline during the sample period was $4012.8 \mathrm{~m}, 4273.9 \mathrm{~m}, 4294.3 \mathrm{~m}$, $4075.3 \mathrm{~m}, 4074.3 \mathrm{~m}, 3697.9 \mathrm{~m}$, and $4232.3 \mathrm{~m}$ in N1, N2, N3, N4, N5, S1, and S2 sites, respectively. 

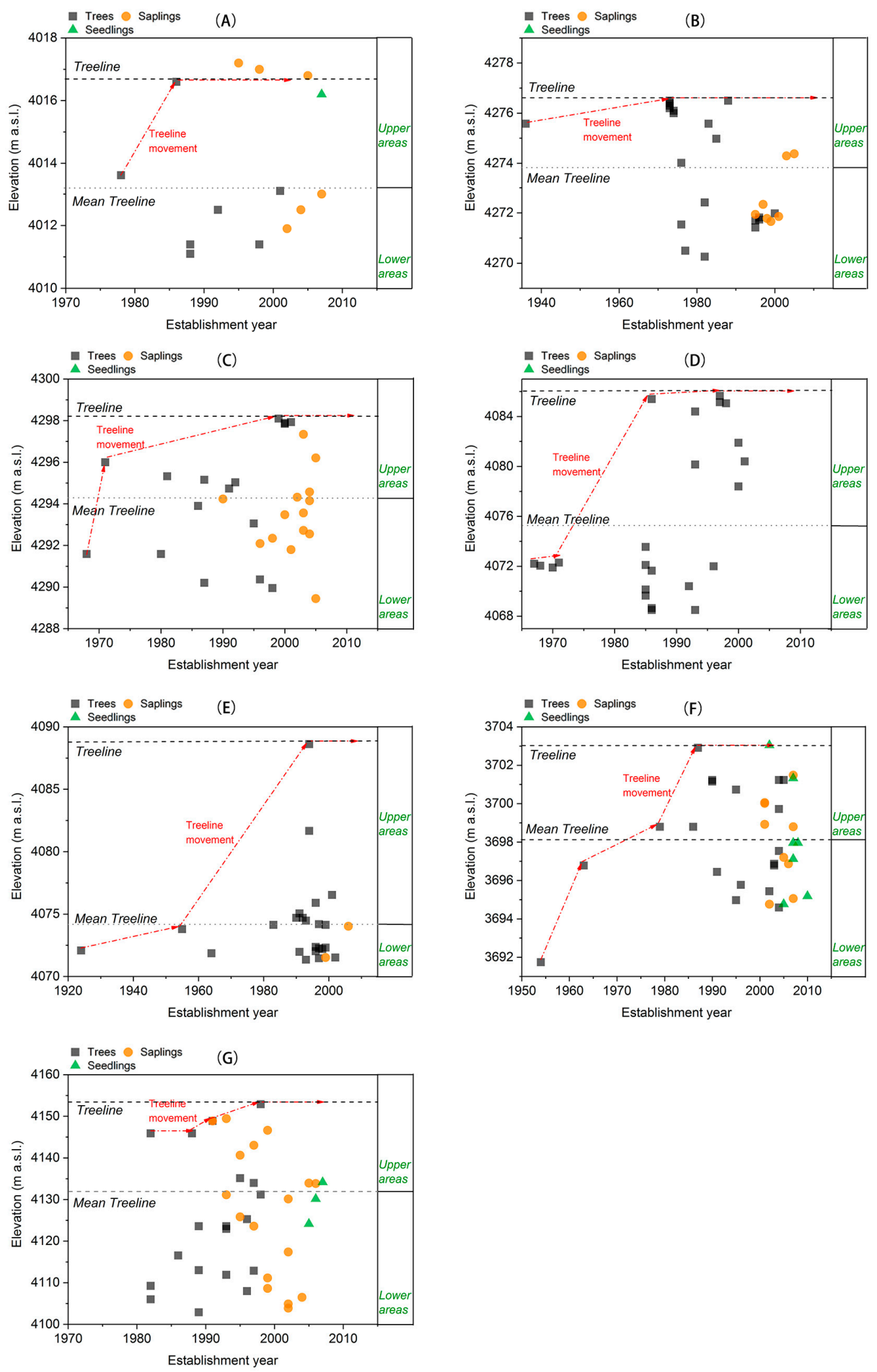

Figure 4. Larix treeline dynamics within each sampling site in the alpine treeline ecotone in the eastern Tibetan Plateau during the period of 1971-2014 ((A): site N1; (B): site N2; (C): site N3; (D): site N4; (E): site N5; (F): site S1; and (G): site S2). Definition of treeline, mean treeline, upper areas, and lower areas are given in the text (see Materials and Methods). Gray-filled squares, orange-filled circles, and green-filled triangles represent trees, saplings, and seedlings, respectively. Treeline movements are shown by the red dash-dot line with arrows. Note the different scale for $\mathrm{x}$ - and $\mathrm{y}$-axes. 


\subsection{Recruitment and Density Dynamics}

The age class distribution of all the sites was skewed shaped, dominated by individuals with younger age classes, except for N4 (Figure 5). The percentage of individuals younger than 20 years is $64.3 \%, 44.4 \%, 67.7 \%, 29.1 \%, 60 \%, 77.1 \%$, and $61.5 \%$ in N1, N2, N3, N4, N5, S1, and S2, respectively. The age distribution of N4 was dominated by individuals with an age class of 21-30. The difference of age distribution of upper areas and lower areas within the sampling sites is shown in the heat map (Figure 5H,I). The age class distribution in both upper and lower areas for all the sites is dominated by younger individuals, which is consistent with the results in the other seven bar charts. Compared with the upper areas, more young individuals were established in the lower areas on both south- and north-facing slopes.
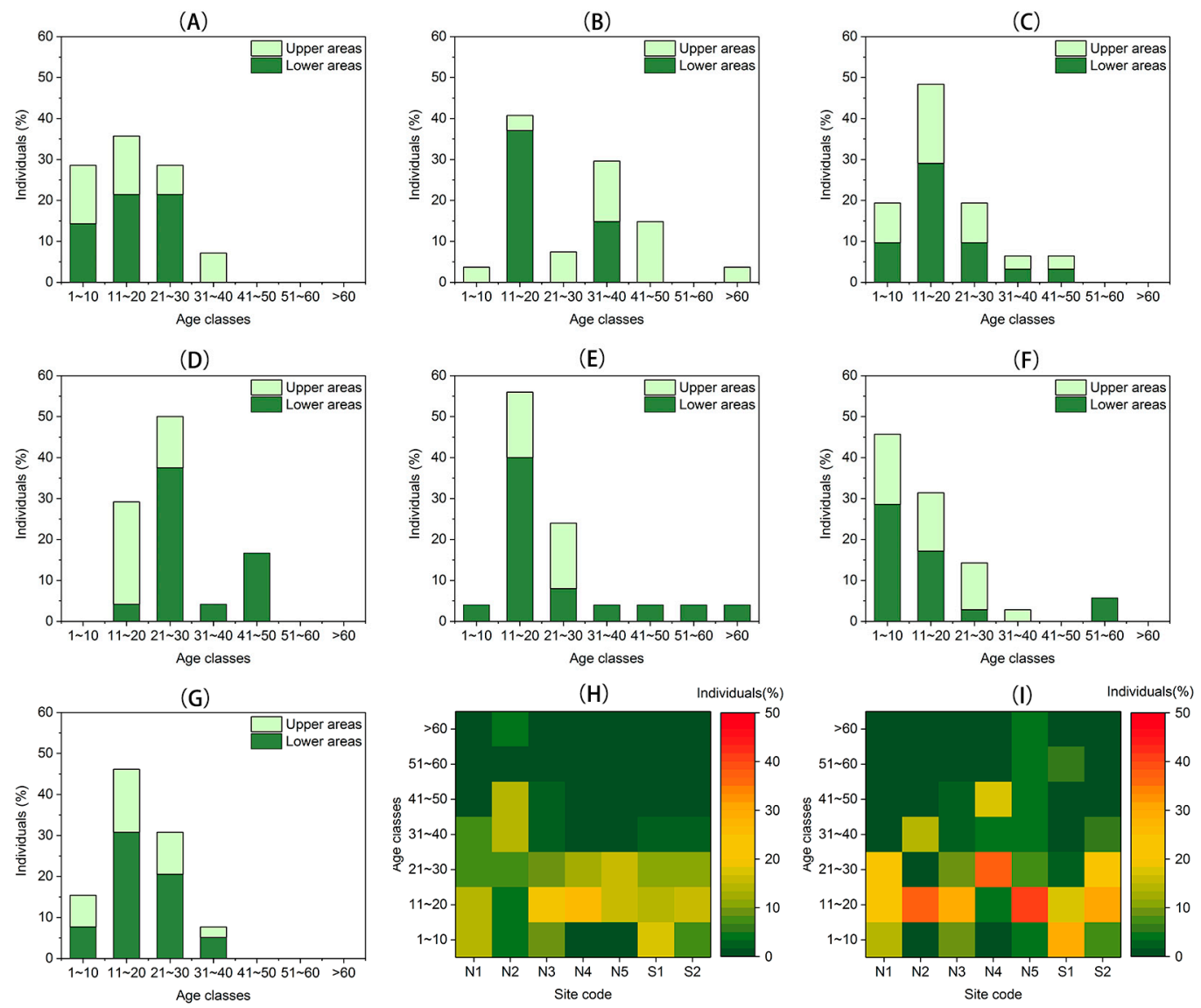

Figure 5. Age structure (10-year interval) of Larix in the alpine treeline ecotone in the eastern Tibetan Plateau during the period of 1971-2014. Seven green bar charts (from Figure 5A-G) show the age structure of Larix in the upper and lower areas within each sampling site ((A): site N1; (B): site N2; (C): site N3; (D): site N4; (E): site N5; (F): site S1; and (G): site S2). Heat maps (Figure 5H,I) at the right bottom show the differences of age structure in upper and lower areas in different sites $((\mathbf{H})$ : upper areas; and (I): Lower areas). The colors from green to red represent lower and higher proportions.

From 1971 onwards, the density of the Larix population on north-facing slopes showed a dramatic increase in both upper and lower areas, approximately following a J-shaped curve (Figure 6). Most of the treeline trees were established during the period of 1985-2005 on north-facing slopes. Density in the lower areas increased more dramatically than the upper areas in all north-facing sites except for N2. The population density on south-facing slopes only showed a slight increase during the sample period. Compared with the north-facing slopes, density dynamics showed no significant difference between the upper and lower areas on south-facing slopes. 

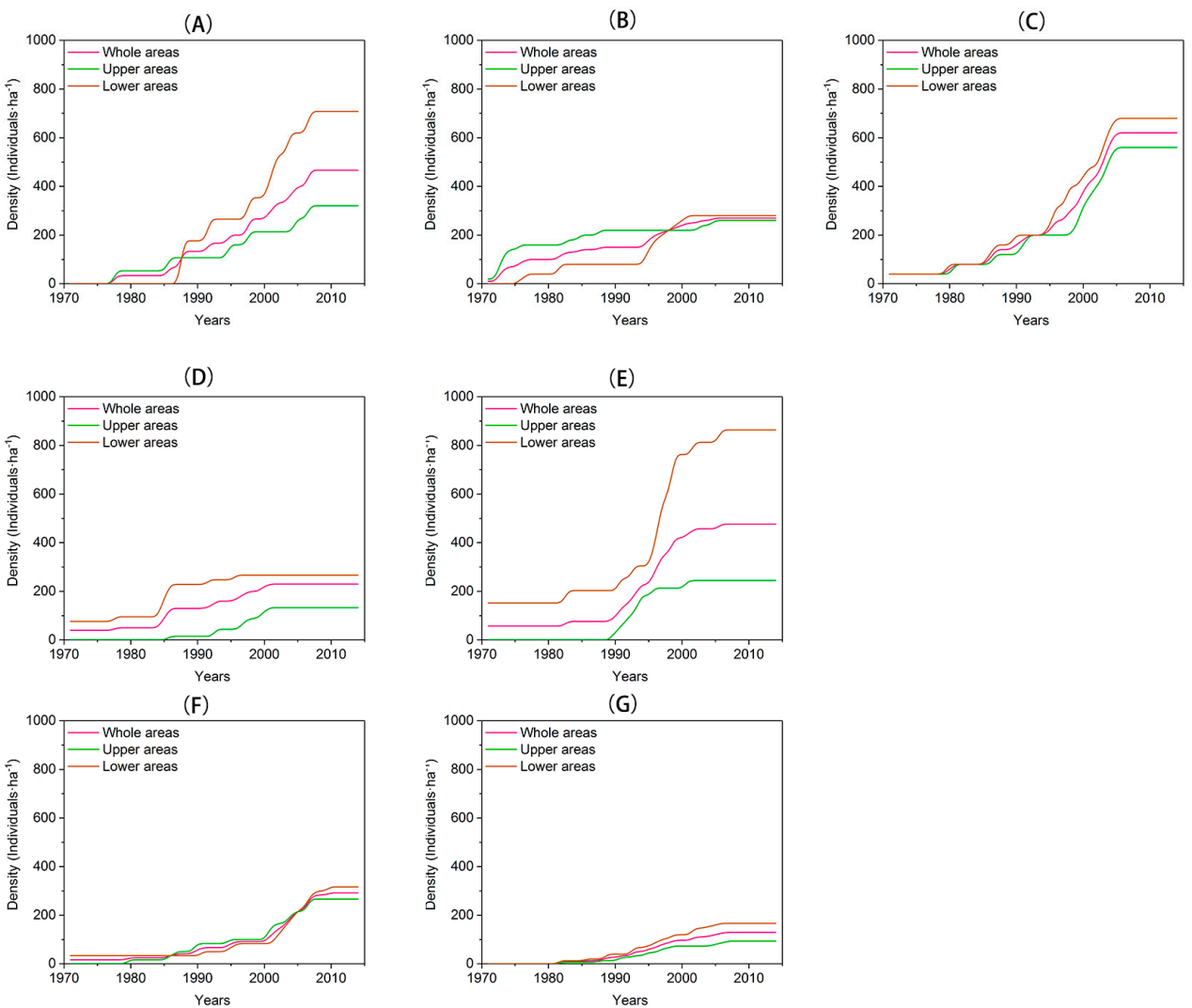

Figure 6. Population density dynamics of Larix within different sampling site in the alpine treeline ecotone in the Eastern Tibetan Plateau during the period of 1971-2014 ((A): site N1; (B): site N2; (C): site N3; (D): site N4; (E): site N5; (F): site S1; and (G): site S2). The pink, green, and brown lines show the density dynamics in the whole, upper, and lower areas, respectively.

The correlation analysis between the population density dynamics and the monthly meteorological data showed the relationship between tree regeneration and climate during the period of 1971-2014 (Table 2). The temperature in the most recent February significantly correlated with tree recruitment in each site. In general, the temperature in the cold seasons (from the previous November to the current March) had a significantly positive impact on the recruitment of Larix. Precipitation in each month, however, had no significant impact on the tree recruitment.

Table 2. Pearson correlation coefficients between population density dynamics of Larix in seven sampling sites in the alpine treeline ecotone in the Eastern Tibetan Plateau and the monthly meteorological data during the period of 1971-2014. The months marked with "** denote months belonging to the previous year. "a" marked at the top right of the circles denotes significance at $p<0.05$, and " $\mathrm{b} "$ denotes significance at $p<0.01$.

\begin{tabular}{|c|c|c|c|c|c|c|c|c|}
\hline & & N1 & N2 & N3 & N4 & N5 & $\mathrm{S} 1$ & S2 \\
\hline \multirow{12}{*}{$\begin{array}{l}\text { Monthly mean } \\
\text { temperature }\end{array}$} & October * & 0 & 0 & 0 & 0 & 0 & $\bigcirc 0$ & \\
\hline & November * & $\bullet$ & - & - & $\bullet$ & $\bullet$ & $\bullet$ & $\bullet$ \\
\hline & December * & $\bullet$ & $\bullet$ & $\bullet$ & $\bullet$ & $\bullet$ & $\bullet$ & $\bullet$ \\
\hline & January & $\bullet$ & $\bullet$ & $\bullet$ & $\bullet$ & • & $\bullet$ & $\bullet$ \\
\hline & February & $\bullet^{\mathrm{a}}$ & $\mathbf{e}^{\mathrm{b}}$ & $\bullet^{\mathrm{b}}$ & $\bullet^{\mathrm{b}}$ & $\bullet^{\mathrm{a}}$ & $\boldsymbol{e}^{\mathrm{b}}$ & $\boldsymbol{\bullet}^{\mathrm{a}}$ \\
\hline & March & $\bullet$ & - & $\bullet$ & $\bullet$ & $\bullet$ & $\bullet$ & - \\
\hline & April & 0 & 0 & 0 & 0 & 0 & 0 & 0 \\
\hline & May & $\bullet$ & $\bullet$ & - & & & - & $\bullet$ \\
\hline & June & - & $\bullet$ & - & $\bullet$ & $\bullet$ & $\bullet$ & $\bullet$ \\
\hline & July & - & 0 & $\bullet$ & 0 & $\bullet$ & - & $\bullet$ \\
\hline & August & $\bullet$ & 0 & $\bullet$ & 0 & 0 & 0 & 0 \\
\hline & September & - & $\bullet$ & - & $\bullet$ & $\bullet$ & $\bullet$ & $\bullet$ \\
\hline
\end{tabular}


Table 2. Cont.

\begin{tabular}{|c|c|c|c|c|c|c|c|c|}
\hline & & N1 & N2 & N3 & $\mathrm{N} 4$ & N5 & S1 & S2 \\
\hline $\begin{array}{l}\text { Total Monthly } \\
\text { precipitation }\end{array}$ & $\begin{array}{c}\text { October * } \\
\text { November * } \\
\text { December * } \\
\text { January } \\
\text { February } \\
\text { March } \\
\text { April } \\
\text { May } \\
\text { June } \\
\text { July } \\
\text { August } \\
\text { September }\end{array}$ & $\begin{array}{l}0 \\
\bullet \\
\bullet \\
\bullet \\
\bullet \\
\bullet \\
\bullet \\
0 \\
0 \\
\bullet \\
\bullet \\
\bullet\end{array}$ & $\begin{array}{l}0 \\
0 \\
0 \\
0 \\
0 \\
\bullet \\
\bullet \\
0 \\
\bullet \\
\bullet \\
0 \\
0\end{array}$ & $\begin{array}{l}0 \\
0 \\
0 \\
\bullet \\
\bullet \\
\bullet \\
\bullet \\
0 \\
\bullet \\
0 \\
0 \\
0\end{array}$ & $\begin{array}{l}0 \\
0 \\
0 \\
\bullet \\
\bullet \\
\bullet \\
\bullet \\
0 \\
\bullet \\
0 \\
0 \\
0\end{array}$ & $\begin{array}{l}0 \\
\bullet \\
0 \\
\bullet \\
\bullet \\
\bullet \\
\bullet \\
0 \\
\bullet \\
0 \\
0 \\
0\end{array}$ & $\begin{array}{l}0 \\
0 \\
0 \\
\bullet \\
0 \\
\bullet \\
\bullet \\
0 \\
\bullet^{b} \\
0 \\
0 \\
0\end{array}$ & $\begin{array}{l} \\
\bullet \\
0 \\
\bullet \\
\bullet \\
0 \\
\bullet \\
0 \\
\bullet \\
0 \\
0 \\
0\end{array}$ \\
\hline
\end{tabular}

Notes: Pearson correlation coefficients between tree density trends and the monthly meteorological data showed the relationship between recruitment and climate during the period of 1971-2014. The months marked with an asterisk * denote months belonging to the previous year, whereas months without * denote months belonging to the current year. The filled circles represent positive correlation, whereas open circles represent negative correlation. ${ }^{a}$ marked at the right top of the circles denotes significance at $p<0.05$ of pearson correlation and ${ }^{\mathrm{b}}$ denotes significance at the $p<0.01$ level.

\subsection{Spatial Distribution Patterns}

Spatial patterns of the Larix population were investigated by using the quadrat-based indices, including $D I, m^{*}, C x$, and $P I$, and are shown in Table 3. In all sites, the DI was greater than $1, C x$ was greater than 0 , and $m^{*}$ was greater than $\bar{X}$, which indicated that the Larix population showed aggregated distribution on both north- and south-facing slopes. With the exception of N2, the upper areas within the sites displayed a lower clump intensity index $(P I)$ than the lower areas, indicating that the clustering process was more dramatic at higher elevation.

Table 3. Spatial distribution pattern of Larix in the total site, upper areas, and lower areas within the seven sampling sites in the alpine treeline ecotone in the eastern Tibetan Plateau over the period of 1971-2014 using the quadrat-based indices, including DI, $m^{*}, C x$, and PI. All of the indices are statistically significant $(p<0.05)$.

\begin{tabular}{ccccccccc}
\hline Site & Item & $\mathbf{N}$ & $\overline{\boldsymbol{X}}$ & $\boldsymbol{S}^{\mathbf{2}}$ & $\mathbf{D I}$ & $\boldsymbol{m}^{*}$ & $\boldsymbol{C} \boldsymbol{x}$ & $\boldsymbol{P I}$ \\
\hline \multirow{3}{*}{$\mathrm{N} 1$} & $\mathrm{~T}$ & 300 & 0.05 & 0.07 & 1.53 & 0.58 & 0.04 & 0.09 \\
& $\mathrm{U}$ & 187 & 0.03 & 0.11 & 4.14 & 3.16 & 0.78 & 0.01 \\
& $\mathrm{~L}$ & 113 & 0.07 & 0.09 & 1.30 & 0.37 & 0.04 & 0.24 \\
\hline \multirow{3}{*}{$\mathrm{N} 2$} & $\mathrm{~T}$ & 1000 & 0.03 & 0.10 & 3.77 & 2.80 & 0.11 & 0.01 \\
& $\mathrm{U}$ & 500 & 0.03 & 0.04 & 1.44 & 0.46 & 0.04 & 0.06 \\
& $\mathrm{~L}$ & 500 & 0.03 & 0.07 & 2.55 & 1.58 & 0.12 & 0.02 \\
\hline \multirow{3}{*}{$\mathrm{N} 3$} & $\mathrm{~T}$ & 500 & 0.06 & 0.06 & 1.00 & 0.07 & 0.00 & 13.70 \\
& $\mathrm{U}$ & 250 & 0.06 & 0.09 & 1.52 & 0.58 & 0.04 & 0.11 \\
& $\mathrm{~L}$ & 250 & 0.07 & 0.07 & 1.05 & 0.12 & 0.00 & 1.26 \\
\hline \multirow{3}{*}{$\mathrm{N} 4$} & $\mathrm{~T}$ & 1200 & 0.02 & 0.02 & 1.23 & 0.25 & 0.01 & 0.09 \\
& $\mathrm{U}$ & 675 & 0.01 & 0.02 & 1.66 & 0.67 & 0.08 & 0.02 \\
& $\mathrm{~L}$ & 525 & 0.03 & 0.04 & 1.37 & 0.40 & 0.03 & 0.08 \\
\hline \multirow{3}{*}{$\mathrm{N} 5$} & $\mathrm{~T}$ & 525 & 0.05 & 0.06 & 1.35 & 0.40 & 0.01 & 0.13 \\
& $\mathrm{U}$ & 328 & 0.02 & 0.04 & 1.49 & 0.52 & 0.07 & 0.05 \\
& $\mathrm{~L}$ & 197 & 0.09 & 0.11 & 1.29 & 0.38 & 0.02 & 0.30 \\
\hline \multirow{3}{*}{$\mathrm{S} 1$} & $\mathrm{~T}$ & 1200 & 0.03 & 0.03 & 1.09 & 0.12 & 0.00 & 0.34 \\
& $\mathrm{U}$ & 600 & 0.03 & 0.03 & 1.19 & 0.21 & 0.01 & 0.14 \\
& $\mathrm{~L}$ & 600 & 0.03 & 0.03 & 1.08 & 0.11 & 0.00 & 0.42 \\
\hline \multirow{2}{*}{$\mathrm{S} 2$} & $\mathrm{~T}$ & 3000 & 0.01 & 0.03 & 2.42 & 1.43 & 0.04 & 0.01 \\
& $\mathrm{U}$ & 1500 & 0.01 & 0.01 & 1.42 & 0.43 & 0.03 & 0.02 \\
& $\mathrm{~L}$ & 1500 & 0.02 & 0.02 & 1.22 & 0.24 & 0.01 & 0.08 \\
\hline
\end{tabular}

Notes: Site: site code; Item: T (Total, the total site), U (Upper areas), L (Lower areas); N: number of the small samplings plots $(1 \times 1 \mathrm{~m}) ; \bar{X}$ : average abundance; $S^{2}$ : variance of abundance; $D I$ : index of dispersion; $m^{*}$ : Lloyd's mean crowding; $C x$ : Green's index PI: clump intensity index; Type: spatial patterns. All of the parameters were significantly different (at the 0.05 level) among the seven sites, as indicated by two-sample Kolmogorov-Smirnov tests. 
The spatial pattern analysis of Larix with different age classes in each site, classified by a 20-year interval, showed the relationship between tree age and spatial distribution pattern (Table 4). In N2 and $\mathrm{N} 5$ only one individual was established to be 60 years ago, thus the value of $C x$ and $P I$ cannot be determined. According to the indices, such as DI, $m^{*}$, and $C x$, Larix individuals with different age classes showed no significant spatial distribution in all sampling sites. However, the value of PI was lower for the older individuals than the younger ones. This indicated that, compared with young individuals, individuals which were established in the early period tend to be clustered.

Table 4. Spatial distribution pattern of Larix with different age classes in the seven sampling sites in the alpine treeline ecotone in the eastern Tibetan Plateau over the period of 1971-2014 using the quadrat-based indices, including $D I, m^{*}, C x$, and PI. All the indices are statistically significant $(p<0.05)$.

\begin{tabular}{|c|c|c|c|c|c|c|c|c|}
\hline Site & $\begin{array}{l}\text { Age } \\
\text { Classes }\end{array}$ & $\mathbf{N}$ & $\bar{X}$ & $S^{2}$ & DI & $m^{*}$ & $C x$ & PI \\
\hline \multirow[b]{2}{*}{ N1 } & $1 \sim 20$ & 300 & 0.03 & 0.06 & 1.87 & 0.90 & 0.11 & 0.03 \\
\hline & $21 \sim 40$ & 300 & 0.02 & 0.41 & 24.67 & 23.68 & 5.92 & 0.00 \\
\hline \multirow{4}{*}{ N2 } & $1 \sim 20$ & 1000 & 0.01 & 0.02 & 1.66 & 0.67 & 0.06 & 0.02 \\
\hline & $21 \sim 40$ & 1000 & 0.01 & 0.01 & 1.39 & 0.40 & 0.04 & 0.03 \\
\hline & $41 \sim 60$ & 1000 & 0.00 & 0.01 & 2.75 & 1.75 & 0.58 & 0.00 \\
\hline & $>60$ & 1000 & 0.00 & 0.00 & 1.00 & 0.00 & / & / \\
\hline \multirow{3}{*}{ N3 } & $1 \sim 20$ & 500 & 0.04 & 0.04 & 1.06 & 0.10 & 0.00 & 0.76 \\
\hline & $21 \sim 40$ & 500 & 0.02 & 0.01 & 0.86 & -0.12 & -0.02 & -0.12 \\
\hline & $41 \sim 60$ & 500 & 0.00 & 0.00 & 1.00 & 0.00 & 0.00 & -2.00 \\
\hline \multirow{3}{*}{ N4 } & $1 \sim 20$ & 1200 & 0.01 & 0.01 & 0.99 & 0.00 & 0.00 & -1.17 \\
\hline & $21 \sim 40$ & 1200 & 0.01 & 0.01 & 1.14 & 0.15 & 0.01 & 0.08 \\
\hline & $41 \sim 60$ & 1200 & 0.00 & 0.01 & 4.24 & 3.25 & 1.08 & 0.00 \\
\hline \multirow{4}{*}{ N5 } & $1 \sim 20$ & 525 & 0.03 & 0.99 & 34.69 & 33.72 & 2.41 & 0.00 \\
\hline & $21 \sim 40$ & 525 & 0.01 & 0.01 & 0.99 & 0.00 & 0.00 & -1.16 \\
\hline & $41 \sim 60$ & 525 & 0.00 & 0.00 & 1.00 & 0.00 & 0.00 & -2.00 \\
\hline & $>60$ & 525 & 0.00 & 0.00 & 1.00 & 0.00 & / & I \\
\hline \multirow{3}{*}{$\mathrm{S} 1$} & $1 \sim 20$ & 1200 & 0.02 & 0.02 & 1.05 & 0.07 & 0.00 & 0.43 \\
\hline & $21 \sim 40$ & 1200 & 0.01 & 0.01 & 1.33 & 0.33 & 0.07 & 0.02 \\
\hline & $41 \sim 60$ & 1200 & 0.00 & 0.00 & 1.00 & 0.00 & 0.00 & -2.00 \\
\hline \multirow{2}{*}{ S2 } & $1 \sim 20$ & 3000 & 0.01 & 0.01 & 0.99 & 0.00 & 0.00 & -1.04 \\
\hline & $21 \sim 40$ & 3000 & 0.01 & 0.00 & 1.00 & 0.00 & 0.00 & -1.07 \\
\hline
\end{tabular}

Notes: Site: site code; N: number of the small samplings plots $(1 \times 1 \mathrm{~m}) ; \bar{X}$ : average abundance; $S^{2}$ : variance of abundance; DI: index of dispersion; $m^{*}$ : Lloyd's mean crowding; $C x$ : Green's index; PI: clump intensity index; Type: spatial patterns. All of the parameters were significantly different (at the 0.05 level) among the seven sites, as indicated by two-sample Kolmogorov-Smirnov tests.

\section{Discussion}

\subsection{Treeline Dynamics and Recruitment}

Temperature in the TP has shown an overall warming trend during recent decades [1]. The CRU meteorological data for 1971-2014 also suggest a dramatic warming trend in our sampling sites (see Figure 3). In recent studies, an apparent shift around $300 \mathrm{~m}$ in 44 years was observed in the fir and birch treeline in the central Himalayas [17]; however, only around $10 \mathrm{~m}$ in 400 years was observed in the Smith fir treeline in the southeastern TP [14] and around $22 \mathrm{~m}$ in the last 130 years was observed in the Abies spectabilis treeline in the Barun Valley, Eastern Nepal [2]. However, the Larix treeline did not display a significant advancement in response to climate warming in the TP both on the north- and south-facing slopes in our study.

Our study suggested that individuals were mainly established during the period of 1985-2005, which is consistent with the age distribution. Several studies have also demonstrated the increase of density during the 20th century in both high-latitude and high-altitude sites in the northern hemisphere $[7,11,46,47]$. The second half of the 20th century was the warmest period on record 
during the past 1000 years on the Tibetan Plateau [14], and the winter temperature has also increased dramatically in our study area (see Figure 2). In our study, Larix recruitment was strongly correlated with temperature in winter or early growing seasons, which was also observed in the Tianshan Mountains, Northwestern China [11]. Warmer winter will lead to higher soil temperature and longer snow-free periods, which could increase the vertical growth of trees [34,47]. A global model of the treeline claimed that the general critical value of mean daily temperature for the onset of wood formation was 8-9 ${ }^{\circ} \mathrm{C}$ [4]. CRU data showed that there were five months (May-September) with monthly average temperatures exceeding $8^{\circ} \mathrm{C}$ here. Warming in winter will promote snow melt earlier and increase the length of the growing season, which is also favorable for tree growth.

However, the rapid growth of seedlings and dwarf individuals is not necessarily correlated with treeline advancement [47]. The establishment of young individuals beyond the present treeline is essential for treeline shift. However, according to the tree age structure, more young individuals were established in the lower areas but not the upper areas in our study region. Spatial analysis showed that individuals which were established in the early period tend to be clustered when compared with the young individuals both on north- and south-facing slopes. Similar to the Ural Mountains [20], old trees in our study region have two main growth forms: a large proportion of single-stemmed trees with one upright stem and a small part of crippled trees or multi-stemmed trees-like individuals, which indicates that the site-specific environment is stressful here. Individuals with a clustered pattern have the ability to improve the harsh environment by providing shade to shelter from wind desiccation and reduce diurnal temperature range [47]. Clustered spatial patterns provide a positive feedback in ameliorating the stressful environment and facilitating upslope establishment [13]. According to the spatial analysis of individuals in upper and lower areas, individuals showed the aggregated spatial pattern and a more dramatic clustering process was found in upper areas. Toward the treeline, the environment becomes much more stressful, so individuals tend to be clustered because there are fewer places that plants can grow successfully [42]. Therefore, climate warming will allow seedlings and saplings to more rapidly achieve a canopy height sufficient enough to withstand the negative effects when extending toward the treeline [34], providing the potential for future treeline advance; however, other limiting factors such as precipitation, topography, and wind exposure also need to be considered.

\subsection{Slope Exposure Effects and Climate Change}

In contrast with the research in the Southwest Yukon, Canada [48], increased population density only showed on north-facing slopes, not with a significant increase on south-facing slopes. For the north-facing slopes in eastern TP, treeline dynamics and recruitment appears to be limited by lower soil temperature and a short growing period [34]. In winter, the thicker snow cover on north-facing slopes could prevent winter stress by insulating root and plant tissues from wind damage, frost, and abrasion, which provides snow protection for individuals in winter [20]. It could also lead to higher soil temperatures in winter, prolonging the availability of soil moisture for the vertical growth of individuals during the growing season [47]. Studies show that the amount of snowfall and subsequent snowpack accumulation can severely limit the length of the growing season and, thus, rates of successful tree establishment within the treeline ecotone [33]. Warmer winter due to the climate change on the north-facing slopes can lead to a longer growing season. Additionally, Elliott et al. [32] defined "drought" as the reduced snowpack which is typical in the upper treeline ecotone where snow constitutes a large proportion of annual moisture. As the result of rising temperature coupled with further reductions in the snowpack, tree species in snow-heavy environments on north-facing slopes will undergo an abrupt demographic process response to "drought-like deficits" to alleviate the snow limitations. This study highlights the importance of frequent snow limitation for tree establishment on north-facing slopes, which supports the results of our density dynamics analysis.

In contrast to the north-facing slopes, wet conditions are necessary for tree regeneration on south-facing slopes [47]. The climate in the alpine treeline ecotone in the eastern margin of TP is more humid than that in the central TP [31,49], which supports our finding that Larix recruitment 
showed no significant correlations with monthly precipitation. Like white spruce on the southern aspects in the subarctic alpine treeline [34], Larix individuals on the south-facing slopes here will not suffer severe drought stress. However, the traditional moisture indices derived from precipitation data cannot necessarily reflect the actual amount of moisture available to plants. More specifically, the temperature-moisture interactions have significant influences on population regeneration dynamics via climatic water deficit [32]. Limited snowpack due to climate warming could cause frost-drought damages on seedlings and saplings [13]. Thus, water stress due to greater sun exposure coupled with the existence of relatively thin soils that have low moisture-holding capacities became the crucial factor limiting the tree regeneration on south-facing slopes. Temperature-induced deficits may be a potential constraint for south-facing sites, like N4 and N5, with the lowest precipitation in our study region.

In general, the slope-climate-moisture interactions have a pronounced impact on tree recruitment, including snow-limited tree establishment on the north-facing slopes and moisture-limited tree establishment on the south-facing slopes.

\section{Conclusions}

Treeline ecotone dynamics including treeline position, population density, and tree recruitment of Larix on the south- and north-facing slopes in the alpine treeline ecotone in the eastern margin of the TP were examined. On both south- and north-facing slopes, the treelines did not show a significant advancement in the past four decades. The population was dominated by young individuals, which tend to be established in the lower areas on these two different slopes. Larix, here, also tend to be clustered, especially in the upper areas. However, population density increased dramatically only on north-facing slopes. Larix, here, suffer from a stressful environment, but the warmer winter due to climate warming could facilitate the vertical growth of seedlings and saplings. Aggregated spatial patterns also provide a positive feedback in ameliorating the harsh environment. The slope-climate-moisture interactions have a pronounced impact on tree recruitment. Snow-limited tree establishment on the north-facing slopes and moisture-limited tree establishment on the south-facing slopes underscore the importance of considering both climatic drivers and non-climatic drivers, such as slope exposure effects, to understand the treeline ecotone dynamics.

Acknowledgments: This work was supported by the funding from National Natural Science Foundation of China (No. 41271094, 40871124). The authors gratefully acknowledge Climate Research Unit (CRU), University of East Anglia for the provision of the gridded datasets (CRU 3.23TS) (http:/ / www.cru.uea.ac.uk/data/) used in this article. We also thank Junqiao Gan and Yuanyuan Song for the assistance of field sampling in this work.

Author Contributions: Jia'nan performed the experiments, analyzed the data and wrote the manuscript; Jihong Qin analyzed the data, and gave suggestions for the data interpretation; Hui Sun applied the project from National Natural Science Foundation of China, conceived the study and designed the experiments.

Conflicts of Interest: The authors declare no conflict of interest.

\section{Appendix A}

Table A1. Characteristics of regional meteorological stations located near the seven sampling sites.

\begin{tabular}{cccccc}
\hline Station Code & Longitude $\left({ }^{\circ} \mathbf{E}\right)$ & Latitude $\left({ }^{\circ} \mathbf{N}\right)$ & $\begin{array}{c}\text { Elevation } \\
(\mathbf{m} \text { a.s.1.) }\end{array}$ & $\begin{array}{c}\text { Duration } \\
\text { Period }\end{array}$ & $\begin{array}{c}\text { Nearby Sampling } \\
\text { Sites }\end{array}$ \\
\hline Yajiang & 101.0 & 30.0 & 2600.9 & $1971-2014$ & N1 \\
Litang & 100.2 & 30.0 & 3948.9 & $1971-2014$ & N2, N3 \\
Maerkang & 102.1 & 31.5 & 2664.4 & $1971-014$ & N4, N5 \\
Kangding & 101.6 & 30.0 & 2615.7 & $1971-1982$ & S1 \\
Xiaojin & 102.2 & 31.0 & 2369.0 & $1971-2014$ & S2 \\
\hline
\end{tabular}


Table A2. Correlation between climate data from the gridded database (CRU) and regional meteorological station during the period of 1971-2014.

\begin{tabular}{cccc}
\hline Station Code & Nearby Sampling Sites & Temperature & Precipitation \\
\hline Yajiang & N1 & $0.997^{* *}$ & $0.992^{* *}$ \\
Litang & N2, N3 & $0.999^{* *}$ & $0.978^{* *}$ \\
Maerkang & N4, N5 & $0.996^{* *}$ & $0.976^{* *}$ \\
Kangding & S1 & $0.996^{* *}$ & $0.959^{* *}$ \\
Xiaojin & S2 & $0.933^{* *}$ & $0.958^{* *}$ \\
\hline \multicolumn{2}{l}{ Notes: ${ }^{* *}$ means data Pearson's correlation is significant at the 0.01 level (2-tailed). }
\end{tabular}

\section{References}

1. Stocker, T. Climate Change 2013: The Physical Science Basis: Working Group I Contribution to the Fifth Assessment Report of the Intergovernmental Panel on Climate Change; Cambridge University Press: Cambridge, UK, 2014; ISBN 110705799X.

2. Chhetri, P.K.; Cairns, D.M. Contemporary and historic population structure of Abies spectabilis at treeline in Barun valley, eastern Nepal Himalaya. J. Mt. Sci. 2015, 12, 558-570. [CrossRef]

3. Hofgaard, A.; Dalen, L.; Hytteborn, H. Tree recruitment above the treeline and potential for climate-driven treeline change. J. Veg. Sci. 2009, 20, 1133-1144. [CrossRef]

4. Körner, C.; Paulsen, J. A world-wide study of high altitude treeline temperatures. J. Biogeogr. 2004, 31, 713-732. [CrossRef]

5. Kullman, L. Recent tree-limit history of Picea abies in the southern Swedish Scandes. Can. J. For. Res. 1986, 16, 761-771. [CrossRef]

6. Major, J.; Kullman, L. Change and stability in the altitude of the birch tree-limit in the southern Swedish Scandes 1915-75. Arct. Alp. Res. 2012, 11, 477. [CrossRef]

7. Camarero, J.J.; Gutiérrez, E. Pace and pattern of recent treeline dynamics: Response of ecotones to climatic variability in the Spanish Pyrenees. Clim. Chang. 2004, 63, 181-200. [CrossRef]

8. Paulsen, J.; Körner, C. GIS-analysis of tree-line elevation in the Swiss Alps suggests no exposure effect. J. Veg. Sci. 2001, 12, 817-824. [CrossRef]

9. Lloyd, A.H.; Rupp, T.S.; Fastie, C.L.; Starfield, A.M. Patterns and dynamics of treeline advance on the Seward Peninsula, Alaska. J. Geophys. Res. Atmos. 2002, 107. [CrossRef]

10. Körner, C. Alpine Treelines: Functional Ecology of the Global High Elevation Tree Limits; Springer: Basel, Switzerland, 2012.

11. Qi, Z.; Liu, H.; Wu, X.; Hao, Q. Climate-driven speedup of alpine treeline forest growth in the Tianshan Mountains, Northwestern China. Glob. Chang. Biol. 2015, 21, 816-826. [CrossRef] [PubMed]

12. Baker, B.B.; Moseley, R.K. Advancing treeline and retreating glaciers: Implications for conservation in Yunnan, P.R. China. Arct. Antarct. Alp. Res. 2007, 39, 200-209. [CrossRef]

13. Harsch, M.A.; Hulme, P.E.; McGlone, M.S.; Duncan, R.P. Are treelines advancing? A global meta-analysis of treeline response to climate warming. Ecol. Lett. 2009, 12, 1040-1049. [CrossRef] [PubMed]

14. Liang, E.; Wang, Y.; Eckstein, D.; Luo, T. Little change in the fir tree-line position on the southeastern Tibetan Plateau after 200 years of warming. New Phytol. 2011, 190, 760-769. [CrossRef] [PubMed]

15. Holtmeier, F.-K.; Broll, G. Treeline advance-driving processes and adverse factors. Lands. Online 2007, 1, 1-33. [CrossRef]

16. Kullman, L.; Öberg, L. Post-Little Ice Age tree line rise and climate warming in the Swedish Scandes: A landscape ecological perspective. J. Ecol. 2009, 97, 415-429. [CrossRef]

17. Panigrahy, S.; Anitha, D.; Kimothi, M.; Singh, S. Timberline change detection using topographic map and satellite imagery. Tropical Ecol. 2010, 51, 87-91.

18. Shrestha, K.B.; Hofgaard, A.; Vandvik, V. Recent treeline dynamics are similar between dry and mesic areas of Nepal, central Himalaya. J. Plant Ecol. 2015, 8, 347-358. [CrossRef]

19. Holtmeier, F.-K. Mountain Timberlines: Ecology, Patchiness, and Dynamics; Springer Science \& Business Media: Berlin, Germany, 2009; Volume 36. 
20. Hagedorn, F.; Shiyatov, S.G.; Mazepa, V.S.; Devi, N.M.; Grigor'ev, A.A.; Bartysh, A.A.; Fomin, V.V.; Kapralov, D.S.; Terent'ev, M.; Bugman, H. Treeline advances along the Urals mountain range-driven by improved winter conditions? Glob. Chang. Biol. 2014, 20, 3530-3543. [CrossRef] [PubMed]

21. Shrestha, K.B.; Hofgaard, A.; Vandvik, V. Tree-growth response to climatic variability in two climatically contrasting treeline ecotone areas, central Himalaya, Nepal. Can. J. For. Res 2015, 45, 1643-1653. [CrossRef]

22. Holtmeier, F.K.; Broll, G. Sensitivity and response of northern hemisphere altitudinal and polar treelines to environmental change at landscape and local scales. Glob. Ecol. Biogeogr. 2005, 14, 395-410. [CrossRef]

23. Juntunen, V.N.S. Natural regeneration of Scots pine and Norway spruce close to the timberline in northern Finland. Silv. Fenn. 2006, 40, 443-458. [CrossRef]

24. Wiegand, T.; Gunatilleke, S.; Gunatilleke, N. Species associations in a heterogeneous Sri lankan dipterocarp forest. Am. Nat. 2007, 170, E77. [CrossRef] [PubMed]

25. Wang, Y.; Camarero, J.J.; Luo, T.; Liang, E. Spatial patterns of Smith fir alpine treelines on the south-eastern Tibetan Plateau support that contingent local conditions drive recent treeline patterns. Plant Ecol. Divers. 2012, 5, 311-321. [CrossRef]

26. Klasner, F.L.; Fagre, D.B. A half century of change in alpine treeline patterns at Glacier National Park, Montana, USA. Arct. Antarct. Alp. Res. 2002, 49-56. [CrossRef]

27. MacDonald, G.M.; Szeicz, J.M.; Claricoates, J.; Dale, K.A. Response of the central Canadian treeline to recent climatic changes. Ann. Assoc. Am. Geogr. 1998, 88, 183-208. [CrossRef]

28. Burga, C.A.; Perret, R. Monitoring of Eastern and Southern Swiss Alpine Timberline Ecotones; Springer Netherlands: Dordrecht, The Netherlands, 2001; pp. 179-194.

29. Shi, P.; Körner, C.; Hoch, G. A test of the growth-limitation theory for alpine tree line formation in evergreen and deciduous taxa of the eastern Himalayas. Funct. Ecol. 2008, 22, 213-220. [CrossRef]

30. Fang, K.; Gou, X.; Chen, F.; Peng, J.; D’Arrigo, R.; Wright, W.; Li, M.-H. Response of regional tree-line forests to climate change: Evidence from the northeastern Tibetan Plateau. Trees 2009, 23, 1321. [CrossRef]

31. Liu, W.; Wang, L.; Chen, D.; Tu, K.; Ruan, C.; Hu, Z. Large-scale circulation classification and its links to observed precipitation in the eastern and central Tibetan Plateau. Clim. Dyn. 2015, 46, 3481-3497. [CrossRef]

32. Elliott, G.P.; Cowell, C.M. Slope aspect mediates fine-scale tree establishment patterns at upper treeline during wet and dry periods of the 20th century. Arct. Antarct. Alp. Res. 2015, 47, 681-692. [CrossRef]

33. Elliott, G.P.; Kipfmueller, K.F. Multiscale influences of climate on upper treeline dynamics in the southern rocky mountains, USA: Evidence of intraregional variability and bioclimatic thresholds in response to twentieth-century warming. Ann. Assoc. Am. Geogr. 2011, 101, 1181-1203. [CrossRef]

34. Danby, R.K.; Hik, D.S. Responses of white spruce (Picea glauca) to experimental warming at a subarctic alpine treeline. Glob. Chang. Biol. 2007, 13, 437-451. [CrossRef]

35. Qiu, D.-Y.; Yang, J.; Feng, L.; Ni, D.-W.; Huang, C.-X.; Li, Z.-H. Complete plastid genome of Larix potaninii var. macrocarpa, an endangered conifer endemic to China. Conserv. Genet. Resour. 2017. [CrossRef]

36. University of East Anglia. Climatic Research Unit. Available online: http://www.cru.uea.ac.uk/data/ (accessed on 20 July 2017).

37. Zhao, T.; Fu, C. Comparison of Products from ERA-40,NCEP-2,and CRU with Station Data for Summer Precipitation over China. Adv. Atmos. Sci. 2006, 23, 593-604. [CrossRef]

38. Wang, T.; Zhang, Q.B.; Ma, K. Treeline dynamics in relation to climatic variability in the central Tianshan Mountains, northwestern China. Glob. Ecol. Biogeogr. 2006, 15, 406-415. [CrossRef]

39. Fritts, H.C. Tree rings and climate. Ecology 1977, 58, 95-99. [CrossRef]

40. Cook, E.R.; Kairiukstis, L.A. Methods of Dendrochronology: Applications in the Environmental Sciences; Springer Science \& Business Media: Berlin, Germany, 2013; ISBN 9401578796.

41. Stokes, M.A. An Introduction to Tree-Ring Dating; University of Arizona Press: Tuscon, AZ, USA, 1996; ISBN 0816516804.

42. Holmes, R.L. Computer-assisted quality control in tree-ring dating and measurement. Tree Ring Bull. 1983. [CrossRef]

43. Buckley, H.L.; Case, B.S.; Vallejos, R.; Camarero, J.J.; Gutiérrez, E.; Liang, E.; Wang, Y.; Ellison, A.M. Detecting ecological patterns along environmental gradients: Alpine treeline ecotones. Chance 2016, 29, 10-15. [CrossRef]

44. Pielou, E. A single mechanism to account for regular, random and aggregated populations. J. Ecol. 1960, 575-584. [CrossRef] 
45. Lashkari, M.; Shahbazvar, N. Spatial distribution pattern of Diaphorina citri Kuwayama (Hem.: Liviidae) on Lime (Citrus aurantifolia) and Orange (Citrus sinensis) in citrus orchards of Iran. Entomol. Appl. Sci. Lett. 2016, 3, 81-87. [CrossRef]

46. Shiyatov, S.; Terent'ev, M.; Fomin, V.; Zimmermann, N. Altitudinal and horizontal shifts of the upper boundaries of open and closed forests in the Polar Urals in the 20th century. Russ. J. Ecol. 2007, 38, 223. [CrossRef]

47. Elliott, G.P.; Kipfmueller, K.F. Multi-scale influences of slope aspect and spatial pattern on ecotonal dynamics at upper treeline in the Southern Rocky Mountains, U.S.A. Ann. Assoc. Am. Geogr. 2010, 42, 45-56. [CrossRef]

48. Danby, R.K.; Hik, D.S. Variability, contingency and rapid change in recent subarctic alpine tree line dynamics. J. Ecol. 2007, 95, 352-363. [CrossRef]

49. You, Q.; Min, J.; Lin, H.; Pepin, N.; Sillanpää, M.; Kang, S. Observed climatology and trend in relative humidity in the central and eastern Tibetan Plateau. J. Geophys. Res. Atmos. 2015, 120, 3610-3621. [CrossRef]

2017 by the authors. Licensee MDPI, Basel, Switzerland. This article is an open access article distributed under the terms and conditions of the Creative Commons Attribution (CC BY) license (http://creativecommons.org/licenses/by/4.0/). 